\title{
A Comparison between Oral Hypoglycemic Agents and Insulin in treating Gestational Diabetes Mellitus regarding their Safety and Efficacy
}

\author{
Mahabbat, Nadin Anam A ${ }^{1}$, Jannah Abdulrahman Alkinani ${ }^{2}$, Hadeel Taha Yahya Alsaadi ${ }^{2}$, Ahdab Faisal \\ Nono $^{2}$, Sara Mutni Almutairi ${ }^{3}$, Narjes Hassan Alawami ${ }^{4}$, Shahad Abdullah Almagboul ${ }^{5}$, Ammar Osama \\ Alaaddin $^{5}$, Talha Kamal Shagdar ${ }^{6}$, Ziyad Abdullah Mandura ${ }^{6}$ \\ 1- King Saud Bin Abdulaziz University For Health Sciences, 2- Ibn Sina National College 3- Al-Qassim \\ University, 4- Jordan University of Science and Technology, 5- Umm Al-Qura University, \\ 6- King Abdulaziz University
}

\begin{abstract}
Background: Gestational Diabetes Mellitus (GDM) is one of the most common comorbidities of pregnancy. It can cause a various complications for both mother, and fetus. Therefore, many studies have been done to evaluate different management measures. Objective: In this study, our objective was to assess the recent literatures regarding the comparison between oral hypoglycemic and insulin in treating GDM regarding the safety and the efficacy. Methods: PubMed database was used for articles selection, and the following keys used in the mesh ("Gestational Diabetes Mellitus/management"[Mesh] OR "Gestational Diabetes Mellitus /metformin"[Mesh] OR "Gestational Diabetes Mellitus /insulin"[Mesh]). A total of 99 articles were found, with further restriction by PubMed filters, and reviewing the articles titles and abstracts the final results were 7 articles. Conclusion: Oral hypoglycemic can be an effective and safe alternative treatment to insulin for women with GDM. There was no significant risk of maternal or neonatal adverse outcome with the use of metformin or glyburide. Treatment with metformin or glyburide was found to be equivalent for both women and newborns. However, metformin was found to be associated with a higher failure rate than glyburide in treating GDM.
\end{abstract}

Key words: Gestational Diabetes Mellitus, Oral hypoglycemic, Insulin, Safety and the efficacy.

\section{INTRODUCTION}

Diabetes mellitus (DM) is a metabolic disorder occurs as a result of multiple risk factors and etiologies. DM is associated with chronic hyperglycemia as a result of a defects in insulin secretion, insulin action, or both, which lead to disturbance of carbohydrate, fat and protein metabolism ${ }^{(1)}$. In pregnancy, DM is considered as a common comorbidity, and places the both mother and baby at risk for a variety of antenatal, intrapartum, and neonatal complications such as, cesarean section delivery, macrosomia, and admission to neonatal intensive care unit (NICU) ${ }^{(2)}$. The World Health Organization (WHO) recommended that Gestational diabetes mellitus (GDM) be diagnosed when hyperglycemia is noticed for the first time at any stage of the pregnancy with one or more of these abnormal values on $75 \mathrm{~g}$ oral glucose tolerance test- fasting plasma glucose 5.1-6.9 $\mathrm{mmol} / \mathrm{L}, 1$-hour plasma glucose $10.0 \mathrm{mmol} / \mathrm{L}$ or 2-hour plasma glucose $8.5-11.0 \mathrm{mmol} / \mathrm{L}^{(1)}$. According to the International Diabetes Federation (IDF), the epidemiology of diabetes during pregnancy is unknown in many countries in the world ${ }^{(3)}$. Nevertheless, more than 21 million pregnancies were affected by diabetes during the year $2013^{(3)}$. Saudi Arabia is among the top ten countries in the world with the highest prevalence of diabetes ${ }^{(3-4)}$. A recent report from Saudi Arabia estimated the prevalence of pregestational diabetes mellitus (Pre-GDM) and gestational diabetes mellitus (GDM) in Riyadh, the capital city of Saudi Arabia, to be $4.3 \%$ and $24.3 \%$, respectively ${ }^{(5)}$. This prevalence reflects high burden of diabetes among pregnant women compared to other populations in the world ${ }^{(6-7)}$. As a result of the various complications that can occur due to gestational DM, several studies have been done to assess the various measures that can help in controlling pregnant women blood sugar levels with any harm to the fetus. In this review we evaluated the various options that help in controlling blood sugar.

\section{METHODOLOGY}

\section{Sample}

PubMed database was used for articles selection, and the following keys used in the mesh ("Gestational Diabetes Mellitus/management"[Mesh] OR "Gestational Diabetes Mellitus /metformin"[Mesh] OR "Gestational Diabetes Mellitus /insulin"[Mesh]). A total of 99 articles were found, with further restriction by PubMed filters, and reviewing 
the articles titles and abstracts the final results were 7 articles. Inclusion criteria, the articles were selected based on the relevance to the project which should include one of the following topics, \{Gestational Diabetes Mellitus Management, Insulin, Metformin, Oral Agents\}. Exclusion criteria, all other articles that did not have one of these topics as their primary end point, or repeated studies.

\section{Analysis}

No software was used, The data were extracted based on specific form that contain (Title of the study, name of the author,
Objective, Summary, Results, and Outcomes), these data were reviewed by the group members. Double revision of each member's outcomes was applied to ensure the validity and minimize the errors.

\section{RESULTS}

We enrolled 7 randomized clinical trials according to our inclusion, and exclusion criteria described above. All of studies aimed at evaluating different types of GDM treatment and their outcomes. The studies characteristics are shown in Table 1.

Table 1: Details of the Enrolled Studies:

\begin{tabular}{|c|c|c|c|c|c|c|}
\hline Study (year) & $\begin{array}{c}\text { Study } \\
\text { Desig } \\
\mathrm{n}\end{array}$ & $\begin{array}{c}\text { Countr } \\
\mathrm{y}\end{array}$ & $\begin{array}{l}\text { Parti } \\
\text { cipan } \\
\text { ts (n) }\end{array}$ & Objective & $\begin{array}{l}\text { Durat } \\
\text { ion }\end{array}$ & Outcome and Conclusion \\
\hline Beyuo et al. & RCT & Ghana & 104 & $\begin{array}{l}\text { To determine if metformin monotherapy } \\
\text { or metformin in combination with } \\
\text { insulin is equally effective as insulin } \\
\text { monotherapy at glycemic control in } \\
\text { diabetes mellitus in pregnancy }\end{array}$ & $\begin{array}{c}1 \\
\text { year }\end{array}$ & $\begin{array}{l}\text { Metformin monotherapy is effective in } \\
\text { achieving glycemic targets in the } \\
\text { management of diabetes in pregnancy. } \\
\text { It is more effective than insulin in } \\
\text { lowering the 2-H Plasma Glucose level }\end{array}$ \\
\hline Moore et al. ${ }^{(9)}$ & RCT & USA & 149 & $\begin{array}{l}\text { To compare the efficacy of metformin } \\
\text { with glyburide for glycemic control in } \\
\text { gestational diabetes }\end{array}$ & $\begin{array}{c}5 \\
\text { years }\end{array}$ & $\begin{array}{l}\text { The failure rate of metformin was } 2.1 \\
\text { times higher than the failure rate of } \\
\text { glyburide when used in the } \\
\text { management of gestational diabetes }\end{array}$ \\
\hline$\underset{(10)}{\text { Hickman }}$ et al. & RCT & USA & 28 & $\begin{array}{l}\text { To compare the safety and tolerability of } \\
\text { metformin to insulin for glycemic } \\
\text { control among women with preexisting } \\
\text { type } 2 \text { and early A } 2 \text { gestational diabetes }\end{array}$ & $\begin{array}{l}2 \\
\text { years }\end{array}$ & $\begin{array}{l}\text { Metformin is a safe, well-tolerated } \\
\text { treatment for the control of overt type } 2 \\
\text { and early gestational diabetes in } \\
\text { pregnancy }\end{array}$ \\
\hline $\begin{array}{l}\text { Niromanesh } \boldsymbol{e t} \\
\text { al. }^{(11)}\end{array}$ & RCT & Iran & 160 & $\begin{array}{l}\text { To evaluate the effect of metformin and } \\
\text { insulin in glycemic control and compare } \\
\text { pregnancy outcome in women with } \\
\text { gestational diabetes mellitus }\end{array}$ & $\begin{array}{l}2 \\
\text { years }\end{array}$ & $\begin{array}{l}\text { Metformin is an effective and safe } \\
\text { alternative treatment to insulin for } \\
\text { women with GDM. There is no } \\
\text { significant risk of maternal or neonatal } \\
\text { adverse outcome with the use of } \\
\text { metformin }\end{array}$ \\
\hline Silva et al. ${ }^{(12)}$ & $\mathrm{RCT}$ & Brazil & 72 & $\begin{array}{l}\text { To assess blood glucose control and } \\
\text { neonatal outcomes when women with } \\
\text { gestational diabetes mellitus were } \\
\text { treated with metformin or glyburide }\end{array}$ & $\begin{array}{l}1 \\
\text { year }\end{array}$ & $\begin{array}{l}\text { Treatment of GDM with metformin or } \\
\text { glyburide was found to be equivalent } \\
\text { for both women and newborns }\end{array}$ \\
\hline $\begin{array}{c}\text { Spaulonci } e t \\
a l .{ }^{(13)}\end{array}$ & RCT & Brazil & 92 & $\begin{array}{l}\text { To evaluate glycemic control in women } \\
\text { receiving metformin or insulin for } \\
\text { gestational diabetes, and to identify } \\
\text { factors predicting the need for } \\
\text { supplemental insulin in women initially } \\
\text { treated with metformin }\end{array}$ & $\begin{array}{l}3 \\
\text { years }\end{array}$ & $\begin{array}{l}\text { Metformin was found to provide } \\
\text { adequate glycemic control with lower } \\
\text { mean glucose levels throughout the } \\
\text { day, less weight gain and a lower } \\
\text { frequency of neonatal hypoglycemia }\end{array}$ \\
\hline$\underset{(14)}{\text { Refuerzo }}$ et $\boldsymbol{a l}$. & RCT & USA & 79 & $\begin{array}{l}\text { To compare weight loss in the first } 6 \\
\text { weeks postpartum among women with } \\
\text { gestational diabetes mellitus (GDM) } \\
\text { treated with metformin or placebo, a } \\
\text { promising therapy to reduce later risk of } \\
\text { progression to diabetes mellitus }\end{array}$ & $\begin{array}{l}6 \\
\text { week } \\
\text { s }\end{array}$ & $\begin{array}{l}\text { Women with GDM lost approximately } \\
6 \mathrm{~kg} \text { by } 6 \text { weeks' postpartum. This was } \\
\text { similar in both groups and resulted in } \\
<50 \% \text { of women achieving their } \\
\text { prepregnancy weight. No evidence of } \\
\text { benefit from metformin was found } \\
\text { through this period }\end{array}$ \\
\hline
\end{tabular}


Table 2: A comparison among the studies that compared metformin with insulin:

\begin{tabular}{|c|c|c|c|c|c|c|c|c|c|c|}
\hline Study & \multicolumn{2}{|c|}{ Beyuo et al. ${ }^{(8)}$} & \multicolumn{2}{|c|}{ Hickman et al. ${ }^{(10)}$} & \multicolumn{2}{|c|}{$\underset{(11)}{\text { Niromanesh }}$ et al. } & \multicolumn{2}{|c|}{ Spaulonci et al. ${ }^{(13)}$} & \multicolumn{2}{|c|}{ Total } \\
\hline $\begin{array}{l}\text { Treatment } \\
\text { type }\end{array}$ & metformin & insulin & Metformin & insulin & metformin & insulin & metformin & insulin & metformin & insulin \\
\hline $\begin{array}{l}\text { Patients } \\
\text { number }\end{array}$ & 43 & 40 & 14 & 14 & 80 & 80 & 47 & 47 & 184 & 181 \\
\hline $\begin{array}{l}\text { Age }(\text { mean } \\
\text { years) }\end{array}$ & 33 & 33 & 36 & 31 & 30 & 31 & 31 & 32 & 32.5 & 31.75 \\
\hline $\begin{array}{c}\text { Pre- } \\
\text { treatment } \\
\text { FBS (mgldl) }\end{array}$ & 150 & 150 & 97 & 95 & 104 & 107 & 102 & 100 & 113.25 & 113 \\
\hline $\begin{array}{c}\text { Post- } \\
\text { treatment } \\
\text { FBS (mgldl) }\end{array}$ & 115 & 119 & 89 & 85 & 86 & 86 & 90 & 88 & 95 & 94.5 \\
\hline $\begin{array}{l}\text { Gestational } \\
\text { age at birth } \\
\text { (weeks) }\end{array}$ & & & 39 & 38 & 38 & 38 & 38 & 38 & 38.33 & 38 \\
\hline $\begin{array}{l}\text { Baby birth } \\
\text { weight }(\mathrm{kg})\end{array}$ & & & 3.2 & 2.9 & 3.3 & 3.4 & 3.1 & 3.2 & 3.2 & 3.17 \\
\hline
\end{tabular}

Table 3: A comparison between the two studies that compared metformin with glyburide:

\begin{tabular}{|c|c|c|c|c|c|c|}
\hline \multirow{2}{*}{ Study } & \multicolumn{2}{|c|}{ Moore et al. ${ }^{(9)}$} & \multicolumn{2}{c|}{ Silva et al. ${ }^{(12)}$} & \multicolumn{2}{c|}{ Total } \\
\hline Treatment type & Glyburide & metformin & glyburide & metformin & glyburide & metformin \\
\hline Patients number & 74 & 75 & 40 & 32 & 114 & 107 \\
\hline Age (mean years) & 29.6 & 31 & 31.5 & 33.6 & 30.55 & 32.3 \\
\hline Pre-treatment FBS (mgldl) & 115 & 115 & 94.1 & 96.8 & 104.55 & 105.9 \\
\hline Post-treatment FBS (mgldl) & 90.9 & 94.3 & 87.7 & 87.2 & 89.3 & 90.75 \\
\hline Failure rate (\%) & 16.2 & 34.7 & 4 & 23 & 10.1 & 28.85 \\
\hline Gestational age at birth (weeks) & 38 & 38 & 38 & 38 & 38 & 38 \\
\hline Baby birth weight (kg) & 3.3 & 3.1 & 3.4 & 3.3 & 3.35 & 3.2 \\
\hline
\end{tabular}




\section{DISCUSSION}

According to the American Diabetes Association, gestational diabetes mellitus has been defined as, any degree of glucose intolerance with onset or first recognition during pregnancy. Although most cases resolve with delivery, the definition applied whether or not the condition persisted after pregnancy and did not exclude the possibility that unrecognized glucose intolerance may have antedated or begun concomitantly with the pregnancy ${ }^{(15)}$. In previous studies such as those carried out by Al-Rowaily et al. ${ }^{(16)}$ and Ardawi et al. ${ }^{(17)}$, indicated that the prevalence of GDM in Saudi women was reported as $12.5 \%{ }^{(16-17)}$. As the ongoing epidemic of obesity and diabetes has led to more type 2 diabetes in women of childbearing age, the number of pregnant women with undiagnosed type 2 diabetes has increased. The prevalence of GDM has increased since 2010 by 2 -fold to 3 -fold, ranging to $51 \%{ }^{(11)}$. This increment is mainly due to the adoption of the new criteria proposed by the International Association of Diabetes and Pregnancy Study Groups (IADPSG) for the screening and diagnosis of GDM. The IADPSG recommended universal screening for GDM and requires a single glucose value above the cut-off value (instead of two) during the OGTT for diagnosis ${ }^{(15)}$. In addition, lower cut-off values are recommended for fasting and 2-hour glucose. Also, Al-Rubeaan et $\boldsymbol{a l}^{(18)}$ related this to that the latter studies were a community household-based studies, and screening for GDM was based on fasting glucose levels only, without performing OGTT, which explains the lower prevalence of GDM in the latter study than in the current studies ${ }^{(18)}$.

During normal pregnancy, a progressive Insulin Resistance develops beginning around mid-pregnancy, and progresses during the third trimester ${ }^{(19)}$. Hormones and adipokines secreted from the placenta, including tumor necrosis factor (TNF)- $\alpha$, human placental lactogen, and human placental growth hormone are the suggested causes of Insulin Resistance in pregnancy according to that found by Barbour et $\boldsymbol{a l}$. $^{(20)}$ In addition, increased estrogen, progesterone, and cortisol during pregnancy contribute to a disruption of the glucose insulin balance. During pregnancy, insulin secretion increases from a woman's pancreas to compensate for the peripheral Insulin Resistance. When a woman's pancreas does not secrete enough insulin to keep up with the metabolic stress of the Insulin Resistance, the development of GDM occurs. In addition, increased maternal adipose deposition, decreased exercise, and increased caloric intake contribute to this state of relative glucose intolerance ${ }^{(19-20)}$.

In a study done on 573 Saudi women, Alfadhli et al. ${ }^{(21)}$ indicated that the prevalence of GDM increased significantly with increasing age, BMI, and diastolic blood pressure. In addition, a history of GDM in previous pregnancies, a history of delivering a malformed child, and a family history of diabetes were other risk factors for GDM. Women with GDM were older, of higher parity, and had less favorable reproductive history compared with non-diabetic pregnant women. There was a significant increase in the rate of previous miscarriage among women with GDM compared with non-diabetic women ${ }^{(21)}$. In a study done in Saudi arabia about the consequences of GDM, Wahabi $\boldsymbol{e t}$ al. ${ }^{(22)}$, showed that almost $25 \%$ of women with GDM had CS delivery. This prevalence is significantly higher than that in the nondiabetic mothers. The tendency toward delivery by CS is often attributed to the increased rate of macrosomia among women with GDM. Macrosomia, shoulder dystocia, and the associated birth injuries are the main neonatal morbidities associated with GDM. The results of Wahabi et al. ${ }^{(22)}$, study showed a 2-fold increase in the frequency of macrosomia among infants of mothers with GDM compared with the nondiabetic controls of the same study ${ }^{(22)}$.

According to American Diabetes Association (ADA), GDM diagnosis can be accomplished with either of two strategies, "One-step" 75-g OGTT or "Two-step" approach with a 50-g (non-fasting) screen followed by a 100-g OGTT for those who screen positive. The onestep strategy is done by performing a 75-g OGTT, with plasma glucose measurement when patient is fasting and at 1 and $2 \mathrm{~h}$, at 2428 weeks of gestation in women not previously diagnosed with overt diabetes. The OGTT should be performed in the morning after an overnight fast of at least $8 \mathrm{~h}$. The diagnosis of GDM is made when any of Fasting: $92 \mathrm{mg} / \mathrm{dL}$ (5.1 mmol/L), $1 \mathrm{~h}: 180$ $\mathrm{mg} / \mathrm{dL}$ (10.0 mmol/L), or $2 \mathrm{~h}: 153 \mathrm{mg} / \mathrm{dL}(8.5$ 
$\mathrm{mmol} / \mathrm{L}$ ) plasma glucose values are met or exceeded. The two-step strategy is done by first performing a 50-g GLT (nonfasting), with plasma glucose measurement at $1 \mathrm{~h}$, at 24-28 weeks of gestation in women not previously diagnosed with overt diabetes. If the plasma glucose level measured $1 \mathrm{~h}$ after the load is $>130 \mathrm{mg} / \mathrm{dL}, 135 \mathrm{mg} / \mathrm{dL}$, or $140 \mathrm{mg} / \mathrm{dL}(7.2$ $\mathrm{mmol} / \mathrm{L}, 7.5 \mathrm{mmol} / \mathrm{L}$, or $7.8 \mathrm{mmol} / \mathrm{L}$ ), proceed to a 100-g OGTT. Step two of the two-step strategy is by performing the 100-g OGTT when the patient is fasting. The diagnosis of GDM is made if at least two of the four plasma glucose levels (measured fasting and $1 \mathrm{~h}, 2 \mathrm{~h}$, $3 \mathrm{~h}$ during OGTT) are met or exceeded ${ }^{(15)}$.

\section{Management}

- Lifestyle modification

After diagnosis, treatment starts with medical nutrition therapy, physical activity, and weight management depending on pre-gestational weight aiming for the targets recommended by the Fifth International Workshop-Conference on Gestational Diabetes Mellitus (Metzger et al) which are fasting $<95 \mathrm{mg} / \mathrm{dL}(5.3 \mathrm{mmol} / \mathrm{L})$ and either $1 \mathrm{~h}$ postprandial $<140 \mathrm{mg} / \mathrm{dL}(7.8$ $\mathrm{mmol} / \mathrm{L})$ or $2 \mathrm{~h}$ postprandial $<120 \mathrm{mg} / \mathrm{dL}(6.7$ $\mathrm{mmol} / \mathrm{L})$. When an appropriate diet, alone or associated with physical exercise, does not suffice to control blood glucose levels in pregnant women, insulin treatment is often initiated $^{(23)}$.

\section{- Medicinal therapy:}

The use of insulin has traditionally been the mainstay in the management of DM in pregnancy not adequately controlled on diet and exercise. Though effective, the use of insulin is associated with some disadvantages such as the inconvenience of repeated injections, high cost, storage problems and hypoglycemia ${ }^{(24)}$.In a retrospective study done in India Rai et al. ${ }^{(25)}$, it was found that Insulin therapy was considerably more expensive. Cost of therapy was almost 5- to 10-fold more expensive than metformin even after excluding the cost of syringes and needles ${ }^{(25)}$.

Metformin improves peripheral insulin resistance and decreases hepatic gluconeogenesis, and is not associated with weight gain or hypoglycemia ${ }^{(11-12)}$. In some of the studies that compared metformin to insulin therapy, they found no significant difference in glycemic control and no significant difference in the proportion of women who were able to achieve their target glycemic goal (Table 2) ${ }^{(8-}$
10-11-13). In addition, metformin was associated with a significantly lower occurrence of hypoglycemic symptoms and readings compared with insulin. However, metformin was associated with high rates of failure to achieve strict glycemic control as a single agent among the studies. The included studies have shown that there was no significant risk of maternal or perinatal adverse outcome with the use of metformin compared with insulin in GDM. Also, they found that the potential advantages of metformin over insulin in maternal weight gain and neonatal birth weight adjusted for gestational age. Regarding maternal weight gain, Refuerzo et al. (14) compared weight loss in the first 6 weeks postpartum among women with gestational diabetes mellitus (GDM) ${ }^{(14)}$. Although metformin's numbers were relatively better than placebo's in the study, they were not significant. The median weight loss was $(6.3$ $\mathrm{kg}$ [range, from 0.3 to 19.8 ] vs $6.5 \mathrm{~kg}$ [range, from 0.3 to 12.1 ], $\mathrm{P}=0.988$ ) and percentage of women achieving reported pre-pregnancy weight $(41.7 \%$ vs. $37.2 \%, \mathrm{P}=0.69)$. However, the study period was short (6 weeks) and longer study periods were recommended.

Glyburide is a second-generation oral sulfonylurea. It functions differently from metformin which is from Biguanides class. According to studies of Rossetti et al. (26), glyburide binds to pancreatic $\beta$-cell receptors to increase insulin secretion, with the effect of increasing the insulin sensitivity of peripheral tissues ${ }^{(26)}$. In 2000, Langer et al. ${ }^{(27)}$ group conducted an RCT to compare between glyburide and insulin in women with GDM. ${ }^{(27)}$ The study demonstrated that glyburide controlled blood glucose as well as insulin in a selected population, with no increase in adverse neonatal outcomes. Two of the included RCTs were conducted to compare the efficacy of metformin with glyburide for glycemic control in GDM; Moore et al. ${ }^{(9)}$ and Silva et al. ${ }^{(12) .}$ They found that treatment of GDM with metformin or glyburide was equivalent for both women and newborns. However, the failure rate of metformin was reported in both papers to be higher than the one of glyburide. Moore et al. ${ }^{(9)}$ found that the failure rate to achieve adequate glycemic control was 2.1 times higher for the metformin group in comparison with the glyburide group (as shown in Table 3). In addition, regarding 
the neonatal outcomes, Moore et al. ${ }^{(9)}$ found a higher rate of non-elective cesarean deliveries $(\mathrm{P}=0.02)$ and smaller birth weights $(\mathrm{P}=0.02)$ in the metformin group. The maternal and neonatal outcomes were otherwise similar between the two groups. On the other hand, in Silva et $\boldsymbol{a l} .^{(\mathbf{1 2})}$ paper, non-elective cesarean deliveries were higher among glyburide group than metformin group but the value was not statistically significant $(\mathrm{P}=0.91)$.

Similar to our study, Berggren et al. ${ }^{(28)}$ also mentioned that metformin is an effective and a safe alternative of insulin, especially if the dose was titrated well, in order to avoid the only concerning side effect, which is lactic acidosis. In addition, they mentioned that metformin can cause gastric upset symptoms such as nausea and flatulence. That is why they recommended taking the drug with the meals. On the other hand, gastric upset was not an adverse effect of glyburide. So, it can be taken 1 hour before the meal ${ }^{(28)}$.

As mentioned in our review, Singh et al. ${ }^{(29)}$ found conflicting results with regard to rates of caesarean delivery. In addition, there was no significant difference in gestational age at birth between the metformin, glyburide and insulin groups, and there was no difference in adverse outcomes ${ }^{(29)}$. Regarding the efficacy, Ryu $\boldsymbol{e t}$ al. ${ }^{\left({ }^{(0)}\right.}$ reported a similar result to our study that metformin was associated with a higher failure rate than glyburide. However, another study mentioned that there were no differences found with regard to glycemic control or therapeutic failure between the two groups ${ }^{(30)}$.

\section{CONCLUSION}

Oral hypoglycemic agents can be an effective and safe alternative treatment to insulin for women with GDM. There is no significant risk of maternal or neonatal adverse outcome with the use of metformin or the use of glyburide. Treatment with metformin or glyburide was found to be equivalently safe for both women and newborns. However, metformin was found to be associated with a higher failure rate than glyburide in treating GDM.

\section{REFERENCES}

1. WHO and International Diabetes Federation (IDF) Technical Advisory Group (2006): Definition and diagnosis of diabetes mellitus and intermediate hyperglycemia: report of a WHO/IDF consultation.

http://www.who.int/diabetes/publications/ diagnosis_diabetes2006/en/

2. Landon MB, Lisa M, Catherine Y et al. (2011): The Relationship Between Maternal Glycemia and Perinatal Outcome. Obstetrics \& Gynecology ,117(2):218-224.

3. International Diabetes Federation (2013): IDF Diabetes Atlas, vol. 6th, International Diabetes Federation, Brussels, Belgium.

4. Majeed A, Adel A, Tawfik K, Riyadh A et al. (2013): Diabetes in the Middle-East and North Africa: An Update. Diabetes Research and Clinical Practice ,103(2): 218-222.

5. Wahabi H, Fayed A, Esmaeil $\mathrm{S}$ et al. (2016): Riyadh Mother and Baby Multicenter Cohort Study: The Cohort Profile. Plos One, doi:10.1371/journal.pone.0150297.

6. Zhu Y, Zhang C (2016): Prevalence of Gestational Diabetes and Risk of Progression to Type 2 Diabetes: A Global Perspective. Current Diabetes Reports, doi:10.1007/s11892-015-0699-x.

7. Guariguata L, Linnenkamp U, Beagley J et al. (2013): Global Estimates of the Prevalence of Hyperglycaemia in Pregnancy. Diabetes Research and Clinical Practice ,103(2): 176-185.

8. Beyuo T, Obed SA, Adjepong-Yamoah K et al. (2015): Metformin versus Insulin in the Management of Pre-Gestational Diabetes Mellitus in Pregnancy and Gestational Diabetes Mellitus at the Korle $\mathrm{Bu}$ Teaching Hospital: A Randomized Clinical Trial. Plos One, doi:10.1371/journal.pone.0125712.

9. Moore L, Clokey D, Rappaport $\mathrm{V}$ et al. (2010): Metformin Compared With Glyburide in Gestational Diabetes." Obstetrics \& Gynecology, 115(1):55-59.

10. Hickman M, Mcbride R, Boggess $\mathrm{K}$ et al. (2012): Metformin Compared with Insulin in the Treatment of Pregnant Women with Overt Diabetes: A Randomized Controlled Trial. American Journal of Perinatology ,30(6):483-490.

11. Niromanesh S, Alavi A, Sharbaf F et al. (2012): Metformin Compared with Insulin in the Management of Gestational Diabetes Mellitus: A Randomized Clinical 
Trial. Diabetes Research and Clinical Practice, 98(3):422-429.

12. Silva JC, Pacheco $\mathrm{C}$, Bizato $\mathrm{J}$ et al. (2010): Metformin Compared with Glyburide for the Management of Gestational Diabetes." International Journal of Gynecology \& Obstetrics, 111(1):37-40.

13. Spaulonci C, Bernardes LS, Trindade TC et al. (2013): Randomized Trial of Metformin vs Insulin in the Management of Gestational Diabetes. American Journal of Obstetrics and Gynecology ,doi:10.1016/j.ajog.2013.03.022.

14. Refuerzo JS, Viteri OA, Hutchinson M et al. (2015): The Effects of Metformin on Weight Loss in Women with Gestational Diabetes: A Pilot Randomized, Placebocontrolled Trial." American Journal of Obstetrics and Gynecology , doi:10.1016/j.ajog.2014.12.019.

15. American Diabetes Association (2017):

2. Classification and Diagnosis of

Diabetes: Standards of Medical Care in

Diabetes-2018. Diabetes Care, 41(1):S13S27.

16. Rowaily M, Abolfotouh M (2010): Predictors of Gestational Diabetes Mellitus in a High parity Community in Saudi Arabia. Eastern Mediterranean Health Journal, 16(6):636-641.

17. Ardawi M, Nasrat HA, Jamal HS et al. (2000): Screening for gestational diabetes mellitus in pregnant females. Saudi medical journal, 21(2):155-161.

18. Al-Rubeaan KH, Al-Manaa TA, Khoja AM et al. (2014): A Community-based Survey for Different Abnormal Glucose Metabolism among Pregnant Women in a Random Household Study (SAUDI-DM). BMJ Open, 4(8) e005906.

19. Catalano PM, Elaine DT, Noreen MR et al. (1991): Longitudinal Changes in Insulin Release and Insulin Resistance in Nonobese Pregnant Women. American Journal of Obstetrics and Gynecology, 165(6): 1667-1672.

20. Barbour LA, Mccurdy TL, Hernandez JP et al. (2007): Cellular Mechanisms for Insulin Resistance in Normal Pregnancy and Gestational Diabetes. Diabetes Care, 30(12):3154.

21. Alfadhli EM, Osman EN, Basri TH et al. (2015): Gestational Diabetes among Saudi Women: Prevalence, Risk Factors and Pregnancy Outcomes. Annals of Saudi Medicine, 35(3): 222-230.

22. Wahabi HA, Esmaeil SA, Fayed A et al. (2013): Prevalence and Complications of Pregestational and Gestational Diabetes in Saudi Women: Analysis from Riyadh Mother and Baby Cohort Study. Journal of the Egyptian Public Health Association, 88(2): 104-108.

23. Metzger BE (1991): Summary and Recommendations of the Third International Workshop-Conference on Gestational Diabetes Mellitus. Diabetes, 40(2):197-201.

24. Feng YE, Huixia Y (2016): Metformin a Potentially Effective Drug for Gestational Diabetes Mellitus: A Systematic Review and Meta-analysis. The Journal of Maternal-Fetal \& Neonatal Medicine, 30(15): 1874-1881.

25. Rai L, Meenakshi D, Kamath A (2009): Metformin - A Convenient Alternative to Insulin for Indian Women with Diabetes in Pregnancy. Indian Journal of Medical Sciences, 63(11):491-497.

26. Rossetti L, Giaccari A, Defronzo R (1990): Glucose Toxicity. Diabetes Care, 13(6): 610-630.

27. Langer O, Deborah L C et al. (2000): A Comparison of Glyburide and Insulin in Women with Gestational Diabetes Mellitus. New England Journal of Medicine, 343(16): 1134-1138.

28. Berggren EK, Boggess KA (2013): Oral Agents for the Management of Gestational Diabetes. Clinical Obstetrics and Gynecology, 56(4):827-836.

29. Singh KP, Rahimpanah F, Barclay $M$ (2015): Metformin for the Management of Gestational Diabetes Mellitus. Australian and New Zealand Journal of Obstetrics and Gynaecology, 55(4): 303-308.

30. Ryu RJ, Karen E, Hebert MF (2014): Gestational Diabetes Mellitus Management with Oral Hypoglycemic Agents. Seminars in Perinatology, 38(8): 508-515. 